\title{
The Bird in a Gilded Cage, Her Trials and Tribulations: Perspectives on Satyajit Ray's
} Charulata

\author{
Bhaswati Bhattacharjee
}

Guest faculty, Department of English, Bethune College, Kolkata, India

\begin{abstract}
The primary object of this paper is to explore the trajectory of the eponymous character Charulata's journey towards her self-actualisation in Satyajit Ray's great cinematic masterpiece and compare it to that of the same character in Tagore's novella Nastanirh on which the movie was based. The paper aims to prove that Charulata, being an important one in all Ray's films centred on women and their individual perspectives, successfully encapsulates the anguish and desolation of the $19^{\text {th }}$ century Bengali women who strove for breaking free from the shackles of age-old traditions and had to cope with the ensuing adversities all alone.
\end{abstract}

Keywords-19 $1^{\text {th }}$ century Bengal, andarmahal, bhadralok society, loneliness, modern woman.

\section{INTRODUCTION}

"Man must be pleased; but him to please

Is woman's pleasure..."

- Coventry Patmore, Angel in the House

In the first issue (1972) of the short-lived American journal Women and Film, the editorial states:

The subjugation of women ... is not limited only within the film industry; they are oppressed by being packaged as images of sex objects, victims or vampires; and they are oppressed within the film theory itself, by the "male critics who celebrate directors like Hitchcock or Sirk for their complexity or irony, or for in some other way rising above their material - often the humble 'woman's picture' or 'weepie'."1

In almost 70 years since Independence, Indian cinema has reshaped and remoulded itself from the era of classic mythological blockbusters to the Bollywoodised remakes of Hollywood's successful films. Along with these thematic and stylistic transformations undergoes a similarly significant transformation in the ways women are portrayed in Indian films. From the gorgeous eye candy or the dumb victim of male chauvinism to the independent protagonist carrying the storyline forward - the journey has not stopped yet. But, somewhere beneath this veneer of nouveau femme there still lies the age-old precept that the fulfilment of a woman's life should be measured by her success only around the kinder, küche, and kirche.

\section{SATYAJIT RAY: A GLIMPSE OF HIS WORKS}

The works of Satyajit Ray (2 May 1921 - 23 April 1992), the immortal auteur of India, have the impalpable power to remain alive as long as cinema remains the effective medium of communication between societies otherwise separated by language, culture, political and social experiences and sheer distance. ${ }^{2}$ As Shyam Benegal says, while remembering a trip to Kolkata in his youth and his very first encounter with Ray's films:

Satyajit Ray had shattered the mould that had bound filmmakers in India to a form of filmmaking that had remained unchanged since the introduction of sound. By a strange coincidence, this was also a time of revolutions in the cinemas of Europe: Italian Neo-realism, French Nouvelle Vague, the Free Cinema of Britain and the post-war films from northern, central and eastern Europe. All these had taken cinema to an exciting new phase.... If there is a single contribution of Satyajit Ray to the world of Indian cinema it would be the path he created for Indian cinema to break free from being selfreferential and imitative of subjects largely lifted 
from Hollywood films, in favour of a standardized urban view of the world that was largely the creation of nineteenth-century urban theatre. ${ }^{3}$

In Indian cinematic tradition, the two opposite genres were the Mythological and the Socials, roughly corresponding to Japan's jidai and gendai-geki. While the Indian Mythological films display "fantastic hokum undiluted by reality", Indian Socials almost drown social issues like caste or gender discrimination in "sentimental, saccharine claptrap" added with tragic endings without any logical solutions. ${ }^{4}$ Ray's films avoid all these traditions and they claim to have as much to do with reality as possible, remaining free even from the slightest touch of artistic exaggeration.

\section{CHARULATA}

Charulata (1964), Ray's very own retelling of Rabindranath Tagore's novella "Nastanirh" ("The Broken Nest"; 1901), was one (and perhaps the most successful one) of the series of films centred on women which were given way by Ray's concern with male subjectivity. Set in the late $19^{\text {th }}$ century Kolkata, the film not only serves as a powerful study of $19^{\text {th }}$ century Bengali society on the threshold of change, it is also an example of Ray's attempts to formulate a feminist standpoint. ${ }^{5}$

$19^{\text {th }}$ century in Bengal was the crucial historic moment when two apparently adversarial forces - one white, imperial, Christian, the other feudal, orthodox, and Hindu - engaged in a clumsy embrace that culminated in the Renaissance of Bengal from which evolved a new class of bourgeois elite - the bhadralok - who were, in Thomas Babington Macaulay's words, "Indian in blood and colour, but English in taste, in opinions, in morals, and in intellect." Charulata describes the paradoxes within such a divided culture which is neither strictly Indian nor wholly British but a peculiar mixture of assimilation and borrowings where the old authenticities have already begun to collapse and the unauthentic comes to reign and becomes inseparable from the sense of the modern.

The story of the film is as follows - Charulata (Madhabi Mukherjee), a woman with a fine taste and subtle sensibility, is married to the opulent bhadralok Bhupati (Sailen Mukherjee) who runs an English newspaper (The Sentinel) that leaves him no time for his young wife. Sensing her loneliness, he invites Charu's brother Umapada (Shyamal Ghosal) and his wife Manda (Gitali Roy) to stay with them and commissions his own cousin Amal (Soumitra Chatterjee) to serve as Charu's intellectual companion and tutor. However, finding no joy in the company of the staid and stolid Manda, Charu turns more and more to Amal until, almost unintentionally, her feelings ripen into love. But her romantic reverie, quietly egged on by the narcissistic Amal, cannot cross the limits as Amal dares not reciprocate Charu's incestuous overtures. Meanwhile, Bhupati entrusts Umapada with the finances of the newspaper, who takes the advantage of the situation and swindles him. Amal, afraid of being the source of a second betrayal, leaves overnight without having his hosts informed. Charu manages to restrain her emotions but fails to curb them when Amal's letter arrives some days later. Bhupati spies Charu sobbing uncontrollably and understands everything. Finally, Charu is left to bear the burden of her "broken nest" and to pick up the pieces of her life in an attempt to reconsolidate her conjugal relation. However, the question of reconciliation is left uncertain at the end of the film.

\section{THE EMERGENCE OF THE NABEENA: THE VISUAL AND MUSICAL SYMBOLS}

Charulata takes us back to the era of the great awakening of Bengal and makes us aware of the fact that the Renaissance was originally a bourgeois male fantasy supported by lofty, utopian ideals, self-indulgence, and an extreme Anglophilia. These Western-educated, wellintentioned representatives of the bhadralok society set out to reform Bengal by wearing Western clothes, spouting the new liberal rhetoric, and even toasting Gladstone's victory in the British general election but they failed to emerge out of the medieval social stigma attached to the idea of women's liberation. They spoke for women's literacy but could not imagine them beyond the choukath or the boundary of the andarmahal or the inner sanctum of the house. Men like Bhupati, who displayed "imperviousness to everything beyond publishing and politics" $"$, were too busy to notice their women's bid to break out of their stereotypical image of $19^{\text {th }}$ century housewives. And men like Amal, who enjoyed women's attention only because it empowered their ego, often proved themselves too weak to dare society or define themselves through transformative choices; they were modern only at the surface, and traditional at the core.

"If Charulata", in the words of Suranjan Ganguly, "is a story about the search for the modern, then its real protagonist is Charu and not the confused men who fumble around her." ${ }^{\prime 8}$ It is not that she understands very well the term 'modern' itself (to which the men have shown overzealous devotion) or can find the logical reason to explain its nature and function. But, from within the andarmahal, her "inner seismograph catches the vibration waves reaching from outside into her seclusion." 9 The film 
begins with the 3 minutes of title sequence with the strains of a sitar picking out a popular Tagore song "Momo chitté, niti nrityé, ke je naaché ..." (Who is it that dances daily in my heart?) while Charu's hands are shown embroidering a ' $\mathrm{B}$ ' on a piece of cloth. Keya Ganguly, who believes that in Charulata, music expresses what the narrative or the picture cannot, contends that this initial song in the background "evokes the rhythms of a blossoming femininity, ...anticipating a future outside the strict space of the story." "If the song's lyrics", she continues, "are about being in step (ta ta thoi thoi - the bols, or beats, taught to young dancers), Charu is shown to be out of step with the person "dancing in her heart", not only because Amal has yet to arrive on the scene but also because she, like Bimala in Ghare Baire, outsteps her spatiotemporal placement within the narrative." 10

In the next $7 / 8$ minutes we take a peep into Charu's world. The scene is virtually wordless except a couple of words of Charu, shouted out to Braja, the servant, asking him to serve tea to 'dadababu' (a formal, thirdperson designation for her husband). In the rest of the scene, we see her wandering aimlessly, browsing through books that do not hold her attention, and finally picking up a lorgnette or a pair of opera glasses through which she observes the world outside from the window. The stark contrast between Charu's confinement within closed walls and the external world is intensified in the medium closeups of Charu trying to catch a glimpse of the alfresco activities by peering through the shutters on the windows. To get a better view, she takes the help of the lorgnette, the first use of which is to improve her viewing of life beyond her shuttered existence and, a little later, to take a closer look of her husband as he walks right past her, immersed in a book, totally unaware of her presence. Finally, as she lets the lorgnette flop down, the camera follows with a sharp pullback, described by Ray himself as "like a flourish with a pen at the end of an essay.... We know that Charu is resigned to her state of loneliness. And this brings the scene to a close."11

As a recurrent motif, the lorgnette serves as more than a mere prop or visual aid, making Charu "recognizable as a figure that crosses over from being a nineteenth century construct to exhibiting our dilemmas about the transparency of vision and modes of knowing." 12 Her attachment to the device - the playful peep at the world outdoor, the expectant look at Bhupati, and in another crucial scene, the irresistible gaze at Amal - is instrumental in making her a representative of the nabeena or the modern woman who seeks clarity of vision despite her ensconced existence within her little world. The glasses bring the world closer to her but "its proximity" remains "only an optical illusion. It invites her to look, but maintains its separateness as the Other." 13 She can only look at the outside world from a distance but cannot really come out of the cocoon of her "stuffy, brocade-line cage of a house." 14 She faces rebuff even within her world, with Bhupati being oblivious to her presence and Amal being equally oblivious to her feelings. It is this pair of opera glasses that also brings her a sudden shock as she catches sight of a woman (probably a neighbour) holding a baby in her arms. "This has an immediate impact on the childless Charu, reminding her, no doubt, of her husband and her distance from him. She lowers the lorgnette, her head turns almost inevitably towards Amal...and she raises the lorgnette again." 15 At this point in the scene, it becomes clear that it is not merely an intellectual companionship but rather an affectionate attention and warmth of love that she yearns for.

In the aforementioned scene (where Charu has to face the painful facts of her life) Charu and Amal are shown together in the garden; while Amal is preoccupied with his writing, Charu, rocking back and forth on the swing, sings a song, "Phulé phulé dholé dholé" (What gentle breeze floats in the flowers?). The song, also one of Tagore's compositions, is based on a Scottish ballad he had heard on his first visit to England. Later in the film, there is the appearance of a mournful classical song by Raja Rammohun Roy at Bhupati's musical soirée celebrating the victory of Gladstone. In contrast with its sombre tune, Charu's song in the previous scene "draws on conventional European tone structures as well as on the formulaic cinematic association of music and romance"16, making her an emblem of the nabeena who can truly imagine the 'modern' within her heart without announcing it loudly.

Apart from the symbolic lorgnette and the musical sequences there are other vital motifs suggestive of Charu's secluded life and her longing for freedom. For example, when she hurries to pick up the lorgnette to get a better view of the outside world from the window, there is an odd visual clash between the vertical railings of the balcony and the swinging lorgnette in her hand - a shot that is repeated when she rushes to show her article, published in Vishwabandhu, to Amal. In both cases, the railings remain the obstacle to having a clear view of both the objects - the lorgnette and the magazine - implying that none of her activities, viz., viewing and writing, can ultimately move from the confinement of 'woman's space'. The opportunities are not altogether denied to her, but she has been continuously reminded throughout the film that the outside world is mainly a domain for men and a woman's most sacred duty is (no matter how much intelligent she is or how much suffocating she feels within her marital trap) 
to keep the domestic sphere intact. The most daring attempt on Charu's part to redefine herself as a true modern woman is when she proposes Bhupati (during their holiday trip at seaside, after Amal's departure) to start a bilingual paper that they will jointly edit. The desperate struggle to forget Amal and ameliorate her conjugal relation obviously underlies this proposal but the uniqueness of the creative idea itself and her confident overtone are too apparent to go unnoticed.

But the future of such an escapist plan becomes bleak as, at the end of the film, Charu has to turn herself from the refuge of literary creativity to the cost she has now to pay for her shattered home. After the sudden discovery of the embarrassing secret, Bhupati, "in order for him to grasp the situation fully ...is shown being driven alone in a horse-drawn carriage for a long time"17, suggesting again that the outside world can offer him at least a momentary shelter, a solitude that is refused to Charu. In the penultimate scene, Charu is shown standing before the mirror, lost in her thoughts, while suddenly, the sound of Bhupati's carriage is heard and Charu hastily draws the line of sindoor (one of the main signs of a married Hindu woman) on her forehead, signifying the lastditch efforts to put things again in order. She cannot (and perhaps does not wholeheartedly wants) to escape from her marital bond, obviously because there is no other option available for her; the film begins with Charu's hands making the handkerchief for Bhupati ${ }^{18}$ and ends with Charu's hands stretched out to Bhupati, fulfilling a circular journey where Amal remains forever as a memory of the violent storm. ${ }^{19}$ The ending of Tagore's novella conveys the idea that the reconciliation is impossible between husband and wife. Bhupati resolves to go to Mysore, leaving Charu alone in Kolkata, but at the last moment, moved by her sudden plea, agrees to let her accompany him. But this time Charu "herself demurs, realizing at this point that the choice between home and world, husband and lover, tradition and modernity needed to have been made much earlier. "Thaak", she says, in the last words of the tale - "let it be" - for the nest, once broken, cannot be repaired." 20 The very last sequence of Ray's film (largely influenced by the ending of François Truffaut's Les Quatre Cents Coups), where Charu gently bids Bhupati enter into the house and the camera freezes at the gesture of the two stretching out their hands to each other, may at first seem to be a hint of a happy ending. But the situation is slightly changed when, in the final long shot, both of them are shown at the end of the veranda and the word Nastanirh appears boldly on the screen in Bengali, suggesting that, not unlike Tagore's story, a "gap will always remain between husband and wife."21

\section{CHARU: THE ARCHETYPAL RAY WOMAN}

In an interview with Cineaste magazine, when asked why the women in his films tend to be "much stronger, more determined, more adaptable and resilient" than the men his films, Satyajit Ray says: "Although they're physically not as strong as men, nature gave women qualities which compensate for that fact. ...The woman I like to put in my films is better able to cope with situations than men." ${ }^{22}$ Charulata, "the archetypal Ray woman"23, conforms completely to this notion. While the earthy Manda, the only other woman character in the film as well as in the novella, is, no doubt, a pracheena or a common, conservative woman concerned only with chewing paan, lolling on bed and playing cards, Charu, obviously, tends towards nabeena. It has sometimes been suggested that Charu resembles, in some ways, Rabindranath's beloved sister-in-law Kadambari Devi (wife of Jyotirindranath Tagore) who committed suicide in 1884 for reasons unknown. As Champa Srinivasan remarks in her article in Silhouette magazine, Kadambari remained the "chief muse" of Rabindranath throughout his life and, most of his works were actually written in memory of and were silently dedicated to his Notun Bouthan. ${ }^{24}$ Ray himself asserts that there is no doubt that when Tagore created Charu, Kadambari was at the back of his mind. ${ }^{25}$ "Charu is also embroiled, as Kadambari herself was, in the conflicts surrounding the role of Bengali women in the later nineteenth century..." ${ }^{26}$, which are still being fought in Mahanagar, Ray's film preceding Charulata. Charu is, in any case, very closely related to Arati, the heroine of Mahanagar, also played by Madhabi Mukherjee. "There the setting is modern," as Penelope Houston puts it in her article in Sight and Sound, "and the girl finds herself forced into unwilling competition with her husband: taking a job, and discovering that she actually enjoys it." If Arati is, as according to Houston, "right out of the chrysalis", Charu is "the most completely realized of all Ray's women. The wife in Mahanagar finds herself in a situation which her personality must expand to meet. Charu, however, is like an Ibsen heroine in that she knows too much about the sources of her own discontent." 27 Another comparison may be drawn between Charu and Bimala (Swatilekha Sengupta) in Ghare Baire (another adaptation of Tagore's novel of the same name by Ray), the ordinary, domestic wife who suddenly discovers herself, after the appearance of Sandip (Soumitra Chatterjee) - the storm in her life as Amal is in Charu's life, as the "queen bee" (as Sandip calls her) and as the Shakti of the motherland. But Bimala is actually a matured version of Charulata; quite unlike Charu, Bimala's passion for Sandip is charged with sensuousness, and, if Charu's plight is heartrending, 
Bimala's misfortune is more grievous and sombre. It is worth remembering here the poster designed by Ray for Ghare Baire: the silhouette of a woman is seen in the doorway and her shadow lays outstretched behind her. If Charulata can be imagined to be the woman standing hesitatingly on the threshold, the gigantic shadow might represent Bimala who has already stepped across it and therefore has known the dire consequences.

\section{CONCLUSION}

Charulata is perhaps "the first sustained study in Indian cinema of a woman's consciousness that seeks to define itself in terms other than those prescribed by her society." 28 It is a tale of an inward journey that takes the prima donna into a deeper anticipation of self-knowledge. As a long period of learning, the journey enables her to come to grips with what she has been previously taught to suppress and ignore and, with her own struggle with her sense of guilt "as she reclaims this "lost" self and brings it to the surface." 28 Charulata becomes the epitome of all those women of 19th century who arrive at a place of selfdiscovery, stumble upon the strictures of tradition, and learn to turn it into a further source of energy and power something that can be described in the immortalized words of T.S.Eliot:

"Bowsprit cracked with ice and paint cracked with heat.

I made this, I have forgotten

And remember."

(- Marina, line 22-24)

The ship of many journeys is withered at the end alright, but it promises to find a mooring after having sailed across the sea of many troubles. Charu's self-inspection and her realization of the terms of the society may be only a little step for herself but her story remains as a giant leap for all those women who are eternally forced to make a choice between the home and the world.

\section{REFERENCES}

[1] Sue Thornham, "Feminism and Film", The Routledge Companion to Feminism and Postfeminism, page 93.

[2] Swapan Mullick, "The Gentle Power That Does It", The Statesman, Puja 2013 issue, page 196.

[3] Shyam Benegal, Foreword, Deep Focus: Reflections on Cinema, page $\mathrm{x}$-xi.

[4] Gerald Mast, A Short History of the Movies, page 396.

[5] Suranjan Ganguly, Satyajit Ray: In Search of the Modern, Chapter 3 ("Charulata: A Woman's Eye"), page 55. Besides Ray's unforgettable screenplay, we should also remember
Bansi Chandragupta's design for the setting of the film as well as Subrata Mitra's cinematography that contributed to the exquisite beauty of the film.

[6] Thomas Babington Macaulay, Speeches, with the Minute on Indian Education, quoted by Suranjan Ganguly, page 56.

[7] Marie Seton, Portrait of a Director: Satyajit Ray, quoted by Suranjan Ganguly, page 59.

[8] Suranjan Ganguly, page 61.

[9] Chidananda Das Gupta, "Ray and Tagore", Sight and Sound, Volume 36, no. 1 (1966-67), quoted by Suranjan Ganguly, page 61. Charulata conforms to Bankim Chandra Chattopadhyay's idea of a modern woman or nabeena, the opposite of which is pracheena or a conservative woman.

[10] Keya Ganguly, Cinema, Emergence, and the Films of Satyajit Ray, Chapter 2 ["The (Un)moving Image : Visuality and the Modern in Charulata"], page 70-71.

[11] Andrew Robinson, Satyajit Ray: The Inner Eye, Chapter 14, ("Charulata/The Lonely Wife, 1964"), page 166.

[12] Keya Ganguly, page 82.

[13] Suranjan Ganguly, page 65-66.

[14] Philip Kemp, "Satyajit Ray", World Film Directors, Vol. II, ed. John Wakeman, quoted by Suranjan Ganguly, page 64 .

[15] Andrew Robinson, page 166.

[16] Keya Ganguly, page 76.

[17] Satyajit Ray, "Charulata Proshonge", translated as "On Charulata" by Gopa Majumdar in Speaking of Films (translation of Bishoy Chalachchitra), page 174.

[18] It is interesting to note that it is this handkerchief with which Bhupati is shown wiping his face while roaming around aimlessly on his carriage after his discovery of Charu's passion for Amal. Bhupati also recognizes the handkerchief and, as Ray himself says: "Different emotions play on his face - there is disbelief, pain, dejection and, finally, pity for Charu." (Gopa Majumdar, page 174). This might also be seen as suggestive of a possibility of reconciliation between them.

[19] In the film, Amal's arrival and departure both are associated with storm. In his first entry there is a kaalboishakhi, an afternoon storm that occurs during the summer in North-East India and in Bangladesh. After his sudden leave, when Charu bursts into tears, holding his letter in her hands, a gust of wind again storms into the room.

[20] Keya Ganguly, page 89.

[21] Madhabi Mukherjee, quoted by Andrew Robinson, page 168.

[22] "Ray on Ray: Cineaste magazine interview with Satyajit Ray", n.pag. www.satyajitray.org.

[23] Cineaste asks Ray: "Is Charulata the archetypal Ray woman?" And he replies: "Yes, she is." n.pag. www.satyajitray.org.

[24] Champa Srinivasan, "A Peek into the World of Kadambari and Charulata", Silhouette magazine, 16 May 2015.

[25] Andrew Robinson, page 159.

[26] Andrew Robinson, page 160.

[27] Penelope Houston, Sight and Sound, Volume 35, no. 1, Winter 1965/66, in Satyajit Ray: An Intimate Master, ed. Santi Das, page 126. 28).

[28] Suranjan Ganguly, page 65. 
[29] Das, Santi, ed. Satyajit Ray: An Intimate Master. Papyrus. 2004. Print.

[30] Eliot, Thomas Stearns. The Waste Land and other poems. Faber and Faber. 1956. Print.

[31] Gamble, Sarah, ed. The Routledge Companion to Feminism and Postfeminism. Routledge. 2001. Print.

[32] Ganguly, Keya. Cinema, Emergence, and the Films of Satyajit Ray. University of California Press. 2014. Web. 18 April 2016.

[33] Ganguly, Suranjan. Satyajit Ray: In Search of the Modern. Penguin Books India Private Limited. 2011. Print.

[34] Georgakas, Dan and Lenny Rubenstein, eds. The Cineaste Interviews: On the Art and Politics of the Cinema. Chicago: Lake View Press. 1982. Excerpts reprinted by SatyajitRay.org. Web. 10 July 2016.

[35] Mast, Gerald. A Short History of the Movies. Oxford University Press. 1981. Print.

[36] Ray, Sandip, ed. Deep Focus: Reflections on Cinema. HarperCollins Publishers India. 2011. Print.

[37] Ray, Satyajit. Bishoy Chalachchitra. trans. Gopa Majumdar (Speaking of Films). Penguin Books India Private Limited. 2005. Print.

[38] Robinson, Andrew. Satyajit Ray: The Inner Eye. André Deutsch Limited. 1989. Print.

[39] Silhouette. 16 May 2015. Web. 18 April 2016.

[40] The Statesman. Puja 2013. Print. 